\title{
9 Money, Politics, and Local Identity
}

\author{
An Inside Look at the 'Diary' of a Twentieth-Century \\ Khampa Trader
}

\section{Lucia Galli}

\begin{abstract}
This chapter analyses the socio-economic role played by Khampa traders in twentieth-century Tibet, focusing in particular on the increasing political and economic power gained in the 1940 s and 1950 s by members of the most influential eastern Tibetan trading firms. The discussion is enriched by information drawn from the travel journal of Khatag Dzamyag, an otherwise unknown Khampa trader. The author's recollection, spanning over a period of thirteen years (1944-1956), mainly spent journeying, trading, and pilgrimaging, provides the scholar with an insider's perspective on events until now known only through the conventional historiographical writing.
\end{abstract}

Keywords: Khampa traders, twentieth-century Tibet, Khampa identity, travel journal.

\section{Introduction}

Recent developments in the field of Tibetan studies have forced an increasing number of scholars - inside and outside the narrow confines

\footnotetext{
Acknowledgements: I am extremely grateful to Charles Ramble for bringing Dzamyag's nyindep to my attention and to Ulrike Roesler for her support during my doctorate at the University of Oxford. I thank Stéphane Gros and Yudru Tsomu for their kind suggestions and helpful comments on the earlier draft of this paper. My deepest appreciation and gratitude go to Tsering Dhondup Gonkatsang, to whose loving memory this work is dedicated. This chapter is the first of a series of publications I aim to dedicate to the life and work of Khatag Dzamyag. The content of his journal (nyindep), as well as its format, much deserve an in-depth analysis the extent of which necessarily falls outside the limited scope of the present work.
}

Gros, Stéphane (ed.), Frontier Tibet: Patterns of Change in the Sino-Tibetan Borderlands. Amsterdam, Amsterdam University Press 2019

DOI: 10.5117/9789463728713_CHO9 
of the discussion on the Sino-Tibetan relationships - to move away from an assumptive framework based on a priori stipulation of identities and boundaries towards a recognition of the main role played by mobility and flux - rather than fixity and stasis - in shaping those territories labelled as 'borderlands'. In this chapter, I approach frontier territories such as the eastern Tibetan regions of Amdo and Kham in light of an understanding of 'borderlands' as 'a dynamic, permeable, and shifting space', following the definition proposed by Gros in his Introduction to the present volume.

The indisputable globalizing character of the world-empire system of the Qing (Brook 2009) determined the rules of cultural, economic, political, social, and military integration and exchange on the borderlands - and the same could be said, to a lesser extent, of the Ganden Phodrang. Nevertheless, the easternmost fringes of the Tibetan plateau were any thing but 'peripheral'. From the late nineteenth to the mid-twentieth centuries, Kham in particular was, to use Gros' (this volume) words, 'a fragmentary politico-religious landscape and complex cultural matrix', both 'multivocal' and 'multilocal'. In the construction of a sense of Tibetanness, political identity failed to match the importance of its cultural and religious counterparts. While becoming de facto subjects of the Manchu Empire by the mid-eighteenth century, the Tibetans living in the multiethnic regions of Amdo and Kham consistently perceived themselves as connected to the central areas of Ü-Tsang by religious and cultural bonds rather than political affiliations. ${ }^{2}$ Khampa identity, with its rich ecological, social, and religious diversity, constitutes a world of its own, diverse from Central Tibet and certainly distinct from China proper.

Whereas the heuristic and analytic convenience of labelling the regions along the Sino-Tibetan frontier as 'borderlands' is irrefutable, the question about the suitability of applying such a term to the whole extension of Kham remains. In his Introduction, Stéphane Gros convincingly broaches the context of the Sino-Tibetan borderlands 'not as a regionally confined space but as process-oriented spatial formation'. By framing the region as 'a fragmentalized space of interconnected and interdependent locales and people', Gros makes of Kham 'a good-to-think-with category'; by operating a topological reversal, he invites us to move away from prior preconceptions based on a Lhasa-centric and/or Sino-centric historical perceptions. To

1 On new takes on the historical, cultural, and socio-economic developments of the SinoTibetan borderlands, see for instance Hayes (2014), Elliot (2014), Gros (2016), Giersch (2010b; 2016).

2 The same concept applies to the westernmost Himalayan regions of Ladakh and the southernmost areas of Bhutan and Sikkim, which fell into the British India orbit in the nineteenth century (Carrasco 1959, 12-13). 
see the Sino-Tibetan borderlands in terms of 'frontier dynamics' accommodates the inherent paradox of Kham, both 'named regional category' and 'heterogenous frontier zone and nexus of power', a grey area where different forms of authority overlapped. Other frontier areas, such as that studied by C. Patterson Giersch in Southern Yunnan province, exhibit a similar pattern:

[F]rontiers [...] were 'borderlands', or regions without clearly defined political boundaries where multiple expansive powers competed for resources and indigenous allies. They were also 'middle grounds', places of fluid cultural and economic exchange where acculturation and the creation of hybrid political institutions were contingent on local conditions. (Giersch 2006, 3-4)

The political fragmentation of Kham, internally divided into a variety of polities and communities, appears to support the perception of Tibet as intrinsically 'stateless' (Samuel 1982). However, the situation on the ground suggests that the main local polities ultimately conceived themselves as 'centres', despite external attempts at peripherization (see Turek, this volume). The seemingly chaotic patchwork of chieftainships, micro-states, and monastic estates presented within itself forms of secular administration of a certain bureaucratic sophistication. That was indeed the case of nineteenth-century Dergé $^{3}$ and early twentieth-century Nangchen, 'a self-referential sphere with a long legacy of religious and political power and autonomy' (Turek, forthcoming). ${ }^{4}$ The establishment in 1939 of the Xikang province further supports the importance that 'peripheral' and 'ethnic' elements played, not only in China's metamorphosis from empire to nation-state, but also in the emergence of a Khampa identity politics (Lawson 2011; Peng 2002).

Whilst the influence exerted by trade and commerce on the process of empire and state-building has been acknowledged by many scholars (e.g. Millward 1998; Perdue 2005; Kim 2008; Giersch, this volume), the way the intertwining of commercialization and political control affected the Sino-Tibetan borderlands is still very much uncertain. External inputs, such as the implementation of state-controlled interventions and the impact on China of European imperialist threats, have been for a long

3 On the history and bureaucratic structure of the kingdom of Dergé, see Hartley (1997).

4 I would like to thank M. Maria Turek for making available to me a copy of her article 'Monastic Obligations, Hat Change and Lhasa Encroachment: Notes on the Economic System in the Historical Kingdom of Nang chen', presented at the Fontainebleau conference (December 2013) 'When the Taxman Cometh: Tax, Corvée and Community Obligations in Tibetan Societies', and soon to be published as part of the proceedings of the SHTS (Social History of Tibetan Societies). 
time presented as the only causes of change in the Sino-Tibetan frontier, yet recent studies prompt the scholars' attention toward a new narrative of change, acknowledging the role of both insiders and outsiders as promoters of socio-economic innovations (Giersch 2010; Tsomu 2016a, 2016b; Bray, this volume). Fresh approaches to political and economic geographies have been recently proposed by different scholars. Whilst talking about the Songpan region of northern Sichuan, for instance, Jack Hayes (2014, xviii) offers a new perspective on the interpretation of trade networks, inter-cultural relations, regional economic cycles, and political and religious developments in Kham, by acknowledging their development as the outcome of indigenous efforts rather than the byproduct of external forces. Such a perspective is in continuation with that of Giersch (2010b) who focuses his attention on the foundations of trading networks and their impacts on the socio-political developments of local societies in Kham, seeing trade - and trade flows - as a heuristic device designed to challenge the confines of traditional spatial categories, moving away from preconceived geographical scales, such as civilizations, empires or nations, and regions.

The transformative power of trade, especially in the Sino-Tibetan borderlands, is better understood through the analysis of the impacts that trading networks have on the local societies. For instance, the local gentry of Dartsedo acted as brokers for Central Tibetan monasteries and merchants, using their indigenous status to safely navigate the cross-cultural environment of the borderlands (Booz 2011; Tsomu 2016a, 2016b). Whereas the tea trade was tightly controlled by Chinese companies in partnership with monasteries located in Yunnan, Sichuan, and Qinghai, the locals used their connections to the territory to act as go-betweens and interpreters between Central Tibetans and Han and Hui merchants. ${ }^{5}$ Trade networks in fact penetrated territories subject to the indirect rule of the Qing empire and the Lhasa-based government, crossing boundaries and incrementing the bargaining power of political representatives and local elites vis-à-vis the 'centre', whether the Manchu court or the Ganden Phodrang.

\section{A Pilgrim's Diary}

The different frontier policies put in act both by the late Qing and the Nationalist and Republican government in the Kham area - subject of many

5 On the vital role of the trading houses (Ch. guō zhuāng) in Dartsedo prior to 1950s, see Booz (2011, 265-318) and Tsomu (2016a). 
recent studies (Wang 2011; Tsomu 2013, 2015; Elliot 2014; Relyea 2015a, 2015b, 2016a, 2016b; Giersch 2014, this volume) - provide the political background to the present chapter. The rising influence of eastern Tibetan merchants on political matters, as well as the emergence of what could be called a 'protoidentitarian' awareness among Khampa traders and their socio-economic role in the decades preceding 1959 are here examined through the lenses of the autobiographical travel journal of Khatag Dzamyag, an otherwise unknown chief-merchant (tsongpön). ${ }^{6}$ The text, originally written in a scroll-paper format and covering a span of thirteen years (1944-1956), mainly spent by the author journeying, trading, and pilgrimaging, was later edited by The Tibet House in Delhi and published by Indraprastha Press in 1997 with a bilingual title - for the sake of convenience, I will henceforth refer to the text by its English heading, i.e. A Pilgrim's Diary: Tibet, Nepal and India 1944-1956. The word 'diary' loosely translates the Tibetan nyindep, a term indicating a category of texts, literary 'day-books' or 'journals', belonging to the wide genre of Tibetan life writing. ${ }^{7}$ Whereas the content and structure of Dzamyag's nyindep - with its lists of private exchanges, monetary transactions, days spent travelling, teachings and empowerments received - support its inclusion in the genre of journal writing, more cautious should be the identification of it as a 'diary'. ${ }^{8}$ The topic concerning the categorization of Dzamyag's work within the Tibetan literary corpus is beyond the scope of the present chapter, suffice to say that the nyindep mirrors the author's self-perception as trader and self-proclaimed pilgrim (né korwa).

Dzamyag's travel account covers what is probably one of the most significant decades in the history of Indo-Sino-Tibetan relationships, and it does so from the perspective of a Tibetan trader mostly interested in depicting himself as a simple pilgrim, in spite of the substantial economic means at his disposal. The problematic and oft-times outright ambiguous attitude shown by the author in regards to the exact amount of his wealth is at

6 Known in Tibetan as tsongpön, these merchants handled trade and business affairs for hundreds of monasteries (Tsomu 2016b, 20). Khatag Dzamyag earned this title by acting as trade agent for one of the labrang of Ngor $\mathrm{E}$ wam chöden, a Sakya establishment in the central region of Tsang.

7 Forms of Tibetan life writing include, but are not restricted to, biography and autobiography (namthar), accounts of previous lives (kyérap, trungrap), personal histories (jungwa, jöpa), receipt records (topyik, senyik), journals and daybooks (nyindep, nyinto) (Quintman 2015, 24).

8 Although the text has a diary format, the retrospective character of the recollecting process, as well as the absence of any 'confessional' features, suggest its categorization as a form of autobiography rather than a personal journal. Given such a difficulty in reaching a clear taxonomy for the text, I will henceforth refer to the work either as 'journal' or nyindep. On Dzamyag's nyindep and its position within Tibetan diary-keeping practices, see Galli (2019). 
the core of several inconsistencies related to the trader's financial means, especially at the time of his departure from his ancestral land of Rabshi, in Gakok (nowadays Yushu prefecture), ${ }^{9}$ an event that marks the beginning of the trader's journey and subsequently of his nyindep. The events leading to what will turn out to be a life-long exile - Dzamyag was never to return to Rabshi - support the notions of 'multivocality' and 'multilocality' proposed by Gros (this volume). Although nominally subsumed within the Xikang province, the territory of Nangchen was still under the political and juridical control of indigenous rulers, as the case of our trader clearly demonstrates. In the first lines of his journal, written in 1944 and recounting events occurred in 1940, Dzamyag briefly summarises his involvement in a feud between representatives of the local ruling family and some of the major reincarnations of a Geluk establishment with which he was connected. Accused of complicity in the murder of the family's heir, Dzamyag was incarcerated, put to trial, and, with no proof of his personal involvement, condemned to six months of prison at the end of which he was ousted as a 'new beggar' (sartrang). The confiscation of his wealth and estate by the lord of Rabshi is indicative of the unchallenged authority wielded by local rulers, regardless of the Nationalist government's ban to any form of indigenous chiefdoms.

The loss of financial means and source of income, reported by the trader as the initial driving force behind his travels, appear to have been partially overcome three years later, when Dzamyag commissioned, as a propitiatory ritual for his departure, a full reading of the Kangyur, a task for which he donated 258 silver sang (Kha stag 'Dzam yag 1997, 12). It appears plausible to ascribe the monetary influx - presented in the journal as a fait accompli - to a fortunate combination of financial shrewdness and social expertise. In particular, the presence of several hints in the beginning of the nyindep reveals the trader's plan to capitalize on the custom of carrying out business transactions on a credit basis. His journey from eastern Tibet to Lhasa was punctuated by continuous business dealings, necessary to settle old debts and loans, and to pay visits to some of the representatives of the local nobility. The socio-economic network built by Dzamyag in the years preceding his journey was not restricted to governmental officials and local nobility but included many representatives of the mercantile world too; traders, tsongpön, and even members of the Sandutsang household, one of the wealthiest Khampa trading families, could be counted among his contacts. 
Although Dzamyag never elaborates on the relationship tying him to the Sandutsang, the connections he made with representatives and brokers of the family suggest a certain familiarity with their dealings. Whereas the largest eastern Tibetan trading firms are relatively well-known, an in-depth socio-historical study of minor trader households who moved their business to Central Tibet in the early twentieth century is still sorely missing. The Pangdatsang, ${ }^{10}$ the Sandutsang, and the Andrutsang paved the way to a substantial number of smaller Khampa trading families, of whose internal organization we know little to nothing. Scanty, yet fascinating, information is contained in an essay-memoir by a Lhakpa Döndrup, a novelist and previous trader, who provides a description of the inner structure of the Lhasa-based Khampa community in which eastern Tibetan trading households played a representative role. The wealthiest among the merchants were appointed as 'headsmen' (gotso) of their own co-regionals, in consideration of both their professionalism and loyalty to a common 'ancestral land', or phayül. According to Lhakpa Döndrup, the Pangdatsang acted as referents for those hailing from the areas of Markham and Sandu, the Gyanagtsang for those from Karzé and Trehor, the Andrutsang and the Jamatsang for the Khampas from Lithang, the Tsatrültsang and the Chödruktsang for those from Gojo, whereas the traders Dampa Lodrö and Abak were the representatives of the people from Tsaprong (Lhag pa don grub 2009, 369). This Lhasa-based community presented a clan-like inner structure, with a leader, recognized as a primus inter pares, acting as spokesman and regulator for his own co-regionals - each phayül maintained and preserved within a larger container fashioned in the terms of a Khampa proto-identity still largely understood by its own members in via negationis. In the light of this, Dzamyag's dealings with the Sandutsang followed an expected line of action: although by then settled in Trehor, the trading firm originated from the area of Gakok, at the easternmost borders of the kingdom of Nangchen, and they must have therefore appeared as the most suitable referents to the Rabshi-born Dzamyag.

As an active member of the Khampa trading communities in Central Tibet, Khatag Dzamyag belonged to the social stratum that Alice Travers $(2013,144)$ calls 'elite commoners'. ${ }^{11}$ By the early twentieth century, the scale of operation of the trade networks connecting Inner Asia to South

10 For more information on the Pangdatsang, see McGranahan (2002, 2015).

11 On social conditions of pre-modern Tibet, with particular attention paid to the central areas of Ü-Tsang, see Carrasco (1959), Stein (1972), Goldstein (1968; 1971; 1973; 1986; 1989a, 1989b); Miller (1987; 1988), Coleman (1998), Barnett (2008), Petech (2013), and Bischoff (2013). 
and Southeast Asia had sensibly increased; due to the expansion of the European influence in India, China, and South Asia, borderland regions became more and more involved in global trade flows (Coales 1919; Teichman 1922; van Spengen 2000; Harris 2013; Giersch 2006, 2010b). Khampa trading families responded to the new market demands by opening branches in some of the most important trade hubs in Tibet, northern India, Sikkim, and Nepal and by shifting their main offices to Lhasa, where they started mingling with the upper strata of the Lhasan society. Interactions between the upper middle stratum and members of the lower ranking aristocracy were common and often officialized by marriage or ennoblement. It was in this fuzziness of social boundaries that Dzamyag and other affiliates of the most important Khampa trading families moved their steps, carefully threading socio-economic networks that allowed them to gain a substantial political weight in a remarkably short amount of time. By opening the path for other ambitious eastern Tibetan traders, the largest trader households contributed, albeit indirectly, to the rise of other eastern Tibetan trading families and their agents, becoming instrumental in the socio-economic consolidation of the 'intermediate class' by fostering the creation of an environment conducive to Dzamyag's business.

In the first eight years following his forced departure from Rabshi (i.e. from 1944 to 1952), Dzamyag struggled to reassert himself financially. He traded mainly on a small to medium scale, often cashing in old debts and resorting to friends' help. Although the nyindep generally lacks detailed information regarding the author's business dealings, the obsessive care with which the author lists the amount of his offerings to the various monasteries and shrines visited along the way contributes to our understanding of his financial conditions. The flow of money - barely a trickle in the 1944-1952 period - increments substantially as from 1953, in the aftermath of a trip to Kalimpong that marked a watershed moment in Dzamyag's life.

Such a change in fortune began in the last months of 1952, when the trader, at the time guest of the Sandutsang at their mansion in Shigatse, was summoned by the treasurer of the Khangsar labrang of Ngor E wam chöden and requested to supervise the investment of some of the abbot's funds in a business venture to Kalimpong. Whereas every Tibetan could be virtually considered a 'born trader' (Bell 1928, 125), only a few had the resources and abilities to achieve the status of monastic trade agent. Interestingly, the call from the Khangsar labrang reached Dzamyag after a five-month stay at the Sakya establishment, where he had attended a series of teachings and empowerments. At the time, he was accompanied by Rinchen Dorje, a business partner and dharma brother from Trehor. Dzamyag's relationship 
with Rinchen Dorje, himself a tsongpön and renowned Sandutsang agent, represents a constant feature in the trader's life, and it is representative of that intangible yet unbreakable network connecting Khampas throughout the plateau and beyond. Rinchen Dorje is in fact first mentioned in a note dated to 1946 in occasion of a visit paid by Dzamyag to Tashilhunpo, and his name appears time and time again as one of the author's business partners (Kha stag 'Dzam yag 1997, 46; 61-62) and companions during his pilgrimage to India (Kha stag 'Dzam yag 1997, 143). Most of the subsequent journal entries are a testimony to the existence of a 'familiar' territory carved by Khampas in a 'foreign' - be it Central Tibetan or Indian - environment; it is through these cultural and social 'corridors' that most of Dzamyag's business transactions occurred. ${ }^{12}$

At the time of his sojourn at Ngor E wam chöden, our trader claimed to have outdone his dharma companions with the generosity of his offerings, a factor that possibly contributed to attracting the attention of the labrang's treasurer: prodigality towards religious institutions was in fact traditionally associated with trustworthiness, a feature expected from a monastic trade agent. It may also be argued that Dzamyag's connection with well-known agents of the Sandutsang may have increased his status in the eyes of his clients. Be as it may, the Khangsar labrang invested in the trading venture more than 15,000 yin gor (dbyin sgor). ${ }^{13}$ Only scanty information is provided in the nyindep regarding the hiring of a caravan leader and two assistants

12 As the journal tells us, from Tashilhunpo, the trader moved to Shalu where he attended the celebrations for the saga dawa (the fourth month of the Tibetan calendar) of the Fire Dog Year (May 1946), together with another companion from Trehor, a monk named Pema Namgyal. Once back in Shigatse, Dzamyag acted as a trade agent for a certain Tashi Norbu, the treasurer and government appointed trader of the Dra'u household, the strongest lord of the Yushu area. At the time he dealt mainly in butter; he transported from Shigatse to Lhasa about $600 \mathrm{~kg}$ and bought on his way back more than 10,500 kg of butter packed into 96 leather bags, paying for each load (c. $13 \mathrm{~kg}$ ) 33 silver coins (sang). In addition to those, he bought further $990 \mathrm{~kg}$ of butter, paying for them 780 silver coins; by selling these goods, he earned more than 26,297 silver sang (Kha stag 'Dzam yag 1997, 68). Again in 1946, he handled trade for a certain Tashi Tsering, an official appointed with the title of secretary and treasurer (drön nyer) (Kha stag 'Dzam yag 1997, 74). Tashi Norbu makes another appearance in a note dated to the second month of the Iron Tiger Year (March 1950), when Dzamyag made a donation to Ngor E wam chöden on his behalf (Kha stag 'Dzam yag 1997, 189)

13 The term yin gor is generally used in Tibetan language to indicate British currency, yet in this context its reading as 'rupees' appears more likely. Indian rupees are usually rendered in Tibetan as hin gor, but at the time of Dzamyag's business venture (1952) the relatively new independence of India could have justified the use of yin either as a near-homophone for hin or as a slight anachronism for the [British]-Indian rupee. I am grateful to Charles Ramble for clarifying the difficult interpretation of the term for me (private conversation, June 2017). 
for the loading of the pack animals; in spite of the lack of details recorded, it is clear that the author was acutely aware of representing the abbot's interests. In his journal he reports to have kept track of all the exchanges on a separate ledger, ${ }^{14}$ presented to the Khangsar treasurer upon his return to the Sakya establishment in Tsang, and to have personally ensured that the goods were safely allocated (Kha stag 'Dzam yag 1997, 224).

From 1953 onwards, Dzamyag's business increased sensibly, ${ }^{15}$ with a ripple-down effect that also affected his religious behaviour. The substantial offerings made by the trader in the decade following $195^{2}$ demonstrate the financial importance that wealthy sponsors, such as the tsongpön and the largest trading families, had for masters and monastic communities, as well as their increasing weight in internal political matters. In the late 1940s, whilst the government of the Ganden Phodrang was desperately evaluating the possibility of a Chinese encroachment on the Tibetan territory, the economic, and consequentially political, influence of largest Khampa trading firms continued to increase. It is evident from Dzamyag's notes that the trade flows connecting the Sino-Tibetan trade hubs (e.g. Dartsedo, Dergé, Jyekundo) to the towns of Central Tibet (e.g. Lhasa, Shigatse, Gyantse) and the market places of India (e.g. Kalimpong, Calcutta) were still very active, despite the political uncertainty. Already in 1947, the Sandutsang were exporting wool directly to the United States and to England (Goldstein 1989b; Sadutshang 2016, 95), a business Dzamyag himself was very familiar with. By 1950 he had already travelled several times to the nomadic areas of Nagchu to collect wool loads to be transported by pack animals to the towns of Shigatse and Lhasa, and from there to Kalimpong. In his business ventures, Dzamyag was often helped either by his nephew Lojam, who acted as his proxy in Kham, or other chief-merchants working for the Sandutsang, mostly hailing from the family's estate in Trehor. As remarked above, the influx of eastern Tibetan traders to the bustling towns of Central Tibet contributed to the creation, already in the early twentieth century, of small bubbles of Khampa identity. Khampa traders, such as Dzamyag, could thus easily find familiar places and names recreated by the expatriated

14 During the trading trip, Dzamyag kept a separate ledger where he noted every transaction, from the goods loaded and unloaded to his own personal expenses; it is unfortunate that he did not include this information in his personal journal. The reference to other textual sources ascribable to the author may explain the general lack of details concerning his business, which could have been recorded on separate ledgers to which the trader had no longer access at the time of writing his nyindep.

15 Like many other traders from the Ü-Tsang, Dzamyag dealt directly with the nomads living in Nagchu and Barkham. 
community. The embedment of the largest trading firms in the social and economic fabric of the Lhasan society did not weaken their perception of their own identity. Acculturation and adaptation were skills necessary to navigate the intricate trade fluxes (Giersch 2010b, 220; Tsomu 2016a, 2016b), but under the Central Tibetan clothing, the language proficiency, the ability to juggle with different cultural schemes, the core of the Khampa merchants' identity never faltered. The identitarian awareness shared by eastern Tibetans clearly transpires from the nyindep as well. Throughout his account, Dzamyag never questions his identity; he is first and foremost a Khampa, and his relation to his homeland deeply influences the way he perceives himself and his surroundings. It is evident in the author's narrative that, to borrow Ovid's words, 'our native soil draws all of us, by I know not what sweetness, and never allows us to forget'. ${ }^{16}$

\section{Political Weight of Traders in Mid-Twentieth-Century Tibet}

Whereas the impact of state policy on Kham is undisputable, even more interesting is the way local people, and especially traders, influenced the political and social developments of the Lhasa-based government in the decades preceding and following the incorporation of Tibet into the People's Republic of China in 1950.

Dzamyag does not discuss political events in his journal, yet passing mentions are made both to the Communist invasion and the Khampa resistance. In an entry dated to the third day of the fourth month of the Earth Pig Year (5 May 1959), the trader records in his nyindep that early in the morning news of calamities caused by 'red flames', as the author calls them, trickled to Shigatse, where he was based. Dzamyag left in a hurry, taking with him only some cloth-wrapped texts and leaving to his nephew Lojam the dispatch of pack animals loaded with food and beddings to the Ngor Luding labrang. From Ngor E wam Chöden, they set off in the direction of Kalimpong, a trip that marked the beginning of their exile in India (Kha stag 'Dzam yag 1997, 248). Despite the pathos transpiring from this brief note, the author does not remark on the dramatic events following the Chinese occupation, and more information on the ensuing events must be gathered from the introduction to the edited version of his journal. Here it is said that, due to such a hasty departure, one of the scroll-papers on which

16 Nescio qua natale solum dulcedine cunctos ducit et inmemores non sinit esse sui (Ovid Ex Ponto III, 35-36). 
the nyindep had been recorded, namely that covering the events from the twenty-fifth day of the sixth month of the Fire Monkey Year (1 August 1956) to the thirteenth of the tenth month of the Earth Dog Year (24 November 1958) was lost in Shigatse, and no trace of it was to be found at the time of publication in 1997 (Kha stag 'Dzam yag 1997,8$).{ }^{17}$

Direct allusions to the political situation of the time may be lacking, yet Dzamyag's nyindep is filled with valuable socio-economic and religious information. By the mid-twentieth century, the largest Khampa trading firms had moved their headquarters to Lhasa; whereas branches were still active along the Sino-Tibetan borderlands, the heads of the households played their cards mainly on the political tables in Lhasa. In the 1940s, members of the Pangdatsang and the Sandutsang were raised to the ranks of the Lhasa government, holding positions as officials, an honour traditionally reserved to the Lhasan nobility (Tsomu, 2016b, 25; Sadutshang 2016, 100-101). While some representatives of the Khampa trading firms made their way into the Ganden Phodrang government, others pursued a more radical affirmation of their local identity, by fostering the ideal of a 'Khampa rule of Kham'. Proposed in 1935 by Gara Lama and enthusiastically embraced by several of the most powerful chieftains and headsmen of eastern Tibet, among whom there was Pangda Topgyal, the movement for a Khampa 'self-determination' and 'self-rule' failed to gain momentum, and it was only in 1949 that the so-called 'Association for the Promotion of Autonomy of Kham and Tibet' was established in Dartsedo (Tsomu 2016b, 32-33). By that time, the Sino-Tibetan borderlands had already become theatre of warfare guerrilla that later developed into the volunteer force group known as 'Four Rivers, Six Ranges' (Chushi Gangdruk), led by another representative of a Khampa trading family, Andrug Gönpo Tashi (Andrutsang 1973; McGranahan 2010).

Interestingly, the frenzy of the time finds no room in Dzamyag's notes. The years $195^{\circ}$ and 1951 are remarkably devoid of any political or social events. He spent most of his time travelling back and forth between Lhasa and Shigatse, visiting monasteries and keeping up with his business transactions. In 1953 the socio-political situation in Rabshi must have appeared quite unfazed, so much so that Dzamyag wrote a letter to the new incarnation of the local monastery, asking about an ailment for himself and one of his sisters in exchange for the livestock still in his possession (Kha stag 'Dzam yag 1997,

17 A brief account of the events that occurred between 1956 and 1961, year of the author's death, is provided in the last of the scrolls preserved by Dzamyag's relatives and handed down to the editors of The Tibet House in the 1990s. 
225). It was clear to the trader which entity wielded authority at the local level: due to Mao's gradualist approach, monasteries and chieftains were still recognized as agents of power in most of the borderlands as late as the mid-1950s. Not much appears to have changed since his imprisonment in 1940; the real power was firmly in the hands of chieftains and reincarnates, who ruled over a complex, 'multivocal' region (Gros, this volume).

As it often occurs with autobiographical writings, minor narratives lay underneath the main one, waiting to be discovered, contextualized, and interpreted against the historical backdrop of the time. As an active member of the trading community, Dzamyag was involved in various communal activities, such as the offering of a golden throne to the Fourteenth Dalai Lama as a sign of appreciation for the 1957-bestowal of the Kälacakra and Lamrim Chenmo teachings to the traders of Kham and Amdo, an event held concurrently with a tenshug (Kha stag 'Dzam yag 1997, 8). ${ }^{18}$ The author seems sincerely unaware of the underlying political significance of the offering, presented in his journal as a pious gesture in a time of uncertainty and struggles. In reality, the ritual, originally proposed and strongly desired by Gönpo Tashi Andrutsang, was part of a carefully planned project. ${ }^{19}$ The news regarding the Dalai Lama's willingness to bestow a three-day initiation with teachings spread like wild fire throughout the Tibetan regions, quickly assuming a nationalistic nature and threatening the Chinese control over the plateau. Gönpo Tashi's initiative, at first restricted to the sole Khampa traders, gained the approval of Jyampa Gyatso, a prominent merchant from Labrang, and consequently the economic support of the whole Lhasa-based Amdowa community. Riding the wave of excitement and public expectations, the committee in charge of the event proposed the donation of a golden throne to be realized with the offerings coming not only from the wealthy traders of Amdo and Kham, but from all the good-willing people of Tibet, in a show of loyalty and faith towards the figure of the Dalai Lama (Andrustang 1973, 51-52; Jamyang Norbu 2014).

18 Elaborate longevity ritual consisting in the making of offerings to the protector deities to ensure the long life of the Dalai Lama (Ardley 2002, xii).

19 One of the most powerful and wealthy Khampa trading households in Lhasa, the Andrutsang played an important role in the years following the Chinese invasion, when their head Gönpo Tashi, a businessman turned into a freedom fighter, created a network of merchants united against the Chinese. Their group, initially focused on exerting pressure over the P.R.C. for the release of political prisoners and spreading support to the Dalai Lama, evolved in 1958 into a guerrilla army, the 'Khams Four Rivers, Six Ranges Tibetan Defenders of the Faith Volunteer Army', best known as 'Four Rivers, Six Ranges' (Chushi Gangdruk). For more information on the Chushi Gangdruk, see Andrugtsang (1973), Ardley (2002), Goldstein (2007), McGranahan (2010). 
The involvement of traders in the political scene was not restricted to members of the most important trading families. In 1956, a merchant from Lithang named Alo Chödze Tsering Dorje, ${ }^{20}$ together with two low-ranking government officials, promoted the creation of a group claiming to represent the masses in their desire for a free Tibet. ${ }^{21}$ The leading organizers of the movement were mainly traders and government officials: Gönpo Tashi Andrutsang himself was among the activists (Powers and Templeman 2012, 439). Despite not having been an active part of the movement, Dzamyag enthusiastically joined the project for the realization of the golden throne, thus adding his economic weight to the political influence the trading community was able to exert on the political scene.

Dzamyag's disconcerting lack of concern regarding the volatile political situation of the time appears less problematic once we keep in mind that, after the signing of agreement, several prominent Tibetans favoured the accommodation with the Chinese Communist Party (C.C.P.). Furthermore, the years between his appointment as tsongpön and his flight into exile saw Dzamyag's focus turning inwards: whereas on a mundane level he actively took advantage of the volatile economic conditions of the time, his narrative persona appears completely absorbed by esoteric rituals and initiations, the money perceived as a mere means towards the accumulation of merit. The news of an imminent arrival of the 'red flames' breaks in on a routine made of offerings, circumambulations, and prayers, suddenly and violently bursting the atemporal bubble created by Dzamyag in his nyindep.

Before concluding my discussion of the political power gained by Khampa traders in twentieth-century Tibet, I would like to briefly pause on the intertwining of religious and economic interests. It is worth noting that there are several references in the nyindep to the presence and direct involvement of representatives of Khampa trading firms to rituals held in the largest monasteries of Central Tibet, regardless of their sectarian denomination. The unbiased approach to all Tibetan Buddhist traditions - a common feature among the eastern Tibetan traders in general, and Khampas in particular - appears to be one of the factors promoting their socio-economic paramountcy in twentieth-century Tibet, as demonstrated by the ease

20 Successful trader, Alo Chödze Tsering Dorje's fortunes came primarily from the commerce between Tibet and India. He was famous for having introduced the use of iron supports, thus revolutionizing the traditional construction techniques (Powers and Templeman 2012, 439). 21 The principal activities carried out by the group consisted in the putting up of posters calling for the end of the Chinese rule, the sponsorship of long-life rituals for the Dalai Lama and the propitiation of wrathful deities, and welfare initiatives in support of the refugees escaped from eastern Tibet (Powers and Templeman 2012, 439). 
with which Pangdatsang Nyigyel dealt with various monastic institutions, regardless of his own family affiliation. Whereas the fostering of religious tolerance and intellectual liberalism has been repeatedly associated with the non-sectarian (rimé) movement, ${ }^{22}$ the economic impact that the nonsectarian values had on the socio-cultural environment of the plateau in the twentieth century appears to be surprisingly understudied. As pointed out by Turek $(2012,429)$, the rimé masters cultivated spiritual goals that 'did not exclude some hints of a political agenda, as they promoted eastern Tibetan cultural value and autonomy'; since non-sectarianism did contribute to the emergence of a socio-political Khampa identity, it may not be far-fetched to ascribe to members of the trading community the application of a similar attitude for the sake of economic gain.

A certain pragmatism was, after all, present since the very beginning of the rimé movement; in the nineteenth century, the royal family of Dergé had prized religious tolerance by supporting six large monasteries of various religious denominations, i.e. Sakya, Nyingma, and Kagyü. At a closer look, though, it is clear that the royal sponsorship was mutually convenient; whereas the establishments enjoyed an official protectorate and could influence the court through the dispatch of royal chaplains, the king could in turn rely on the presence of strong local monasteries to contain the rise of influence of the Geluk school, and, with it, the political encroachment of the Ganden Phodrang government. Dergé and Nangchen are but two instances where realpolitik used the rimé values to pursue non-religious aims; I would suggest, as a working hypothesis, that the same could be said of the economic pragmatism shown by Khampa traders, such as Pangdatsang Nyigyel and Dzamyag himself, in their dealings with establishments of diverse religious denomination. Prodigality towards monastic institutions was in fact traditionally associated with trustworthiness, a feature expected from a monastic trade agent; by proving their religious piety and supporting the 'field of merit' ${ }^{23}$ that was the religious community, the traders increased their social status and influence.

\footnotetext{
22 The mid-nineteenth century saw the reinvigoration of a non-sectarian approach and the revival of minor lineages and practices; this tendency, controversially defined in Western scholarship as a 'movement', deeply imbued the socio-cultural environment of eastern Tibet, thus providing unifying values to the growing Khampa trading communities that had relocated to Ü-Tsang. On the rimé movement, see Samuel (1993), Gardner (2006), Powers (1995), Smith (2001), and Turek (2013). 23 The idea of monastic communities (Skt. saingha) as a 'field of merit' (Skt. punyakṣetra; Tib. tsokzhing) is found in many Pāli texts. The laymen's offerings to the monastic community are conceived as seeds of good karma sown in the 'field of merit'; by bringing them to fruition, the sangha allows the donors to reap the benefits of their actions (Mills 2003, 61).
} 


\section{Conclusion}

It is said that history is made of personal stories, and Dzamyag's is certainly one of them. The perspective provided by his journal is rather unique: trader and pilgrim, Khampa and Tibetan, sponsor and protégé, the text offers the scholar of pre-modern Tibetan history a different point of view on events mainly known through the formal channels of history making. The emergence of a proto-identitarian awareness among the Khampas in the first decades of the twentieth century goes hand in hand with the increasing political influence exerted by the largest trading firms hailing from eastern Tibet. As early as the 1930s and 1940s, indigenous movements aimed at local independence appeared in southwest China - in particular in Sichuan and, from 1939, in the Xikang province. The majority of the Khampa self-rule movements evolved militantly toward the goal of autonomy, a sentiment that kept simmering even during Mao's gradualist approach in the early 1950s (Peng 2002, 77). In the first half of the twentieth century, the combination of the Khampa 'ancient sense of centrality', as Michael Aris $(1992,13)$ aptly puts it, and the concepts of 'self-determination' and 'self-rule' that began to circulate globally created an explosive situation. The establishment of the 'Four Rivers, Six Ranges', a resistance group set up by Gönpo Tashi Andrugtsang, was met with enthusiasm by the representatives of the other trading families; Lo Gendun Sandutsang joined the guerrillas and died helping the Dalai Lama to flee Lhasa in 1959; Rapga Pangdatsang, despite maintaining his pro-Kuomintang view, actively participated in the revolts against the Communists.

Dzamyag's journal offers an insider's glimpse of two decades - the 1940s and the 1950s - that had been crucial to the history of Tibet. Member of the 'elite commoners' and active participant of the expatriated community of Khampa traders in the central regions of Ü-Tsang, the author does not dwell on the political events of the time, providing the scholars with cause for reflection on the perception harbored by those sections of society not involved in the decision-making process regarding the rapid changes occurring in the Sino-Tibetan relationships. At the same time, his account bears testimony to the correlation between economics and politics: the heavy reliance of the Tibetan government on the services of the Khampa traders gave them considerable bargaining power in the political field. The role played by commerce and trade networks in shaping the empire and nation-building in China was partially replicated in Tibet as well: the tight-knit communities of Khampa traders living in the Central Tibetan towns of Lhasa, Shigatse, and Gyantse used their economic influence to 
shape the nation-building process, strengthening in the meanwhile their own sense of local centrality. As noted by Giersch (2014, 379-380) 'transfrontier merchants were people who engaged with new ideas, created new types of families, and, ultimately, were actively engaged in the major transformations of China, Burma, and - to a lesser degree - India.' In this chapter, I have tried to highlight the transformative power exerted by other transfrontier merchants, namely the Khampa traders, in shaping the politics of Tibet in the first half of the twentieth century.

\section{Glossary of Tibetan Terms}

$\begin{array}{ll}\text { Abak } & \text { A bag } \\ \text { Andrustang } & \text { A 'brug tshang } \\ \text { Chamdo } & \text { Chab mdo } \\ \text { chöyön } & \text { mchod yon } \\ \text { Chödruktsang } & \text { Chos drug tshang } \\ \text { Chushi Gangdruk } & \text { Chu bzhi sgang drug } \\ \text { Dampa Lodrö } & \text { Dam pa Blo gros } \\ \text { dowo } & \text { do bo } \\ \text { drönnyer } & \text { mgron gnyer } \\ \text { Dzawa Pomda } & \text { Rdza ba Spom mda' } \\ \text { Gakok } & \text { Sga khog } \\ \text { Ganden Phodrang } & \text { Dga' ldan pho brang } \\ \text { Geluk } & \text { Dge lugs } \\ \text { gotso } & \text { 'go gtso } \\ \text { Gyanagtsang } & \text { Rgya nag tshang } \\ \text { Jamatsang } & \text { Ja ma tshang } \\ \text { jöpa } & \text { brjod pa } \\ \text { jungwa } & \text { byung ba } \\ \text { Kagyü } & \text { Bka' brgyud } \\ \text { khel } & \text { khal } \\ \text { kyérap } & \text { skyes rab } \\ \text { labrang } & \text { bla brang } \\ \text { Lhakpa Döndrup } & \text { Lhag pa don grub } \\ \text { namthar } & \text { rnam thar } \\ \text { nékorwa } & \text { gnas skor ba } \\ \text { nyak } & \text { nyag } \\ \text { nyindep } & \text { nyin deb } \\ \text { Nyingma } & \text { Rnying ma } \\ & \end{array}$




$\begin{array}{ll}\text { nyinto } & \text { nyin tho } \\ \text { Pangdatsang } & \text { Spang mda' tshang } \\ \text { rimé } & \text { ris med } \\ \text { Saga dawa } & \text { sagazla ba } \\ \text { Sakya } & \text { Sa skya } \\ \text { Sandutsang } & \text { Sa'du tshang } \\ \text { sang } & \text { srang } \\ \text { sartrang } & \text { gsar sprang } \\ \text { senyik } & \text { gsangyig } \\ \text { Tashilhunpo } & \text { Bkra shis lhun po } \\ \text { topyik } & \text { thobyig } \\ \text { trung rap } & \text { 'khrungs rabs } \\ \text { Tsatrültsang } & \text { Tsha sprul tshang } \\ \text { tsokzhing } & \text { tshogs zhing } \\ \text { yingor } & \text { dbyin sgor/hin sgor }\end{array}$

\section{References}

Andrugtsang, Gompo Tashi. 1973. Four Rivers, Six Ranges: Reminiscences of the Resistance Movement in Tibet. Dharamsala: Information and Publicity Office of H.H. the Dalai Lama.

Ardley, Jane. 2002. The Tibetan Independence Movement: Political, Religious and Gandhian Perspectives. London: Routledge Curzon.

Aris, Michael. 1992. 'The Tibetan Borderlands'. In Lamas, Princes, and Brigands:Joseph Rock's Photographs of the Tibetan Borderlands of China, edited by M. Aris, P.R. Booz, S.B. Sutton, 13-19. New York City: China House Gallery, China Institute in America.

Barnett, Robert. 2008. 'What Were the Conditions Regarding Human Rights in Tibet before Democratic Reform?' In Authenticating Tibet: Answers to China's 100 Questions, edited by A. Blondeau and K. Buffetrille, 81-84. Berkeley: University of California Press.

Bischoff, Jeannine. 2013. 'Right There but Still Unnoticed: Information on dGa' ldan pho brang Mi ser from Archival Material Published in Germany'. In Tibetans who Escaped the Historian's Net: Studies in the Social History of Tibetan-speaking Societies, edited by Charles Ramble, Peter Schwieger and Alice Travers, 9-25. Kathmandu: Vajra Books.

Booz, Patrick R., 2011. Tea, Trade and Transport in the Sino-Tibetan Borderlands. DPhil thesis. University of Oxford.

Brook, Timothy. 2009. 'Tibet and the Chinese World-Empire'. In Empires and Autonomy: Moments in the History of Globalization, edited by William D. Coleman, 
Stephen M. Streeter, and John C. Weaver, 24-40. Vancouver: University of British Columbia Press.

Carrasco Pizana, Pedro. 1959. Land and Polity in Tibet. Seattle: University of Washington Press.

Coales, Oliver. 1919. 'Economic Notes on Eastern Tibet'. The Geographical Journal 54 (4): 242-247.

Coleman, William M. 1998. 'The Discourse of Serfdom in Tibet'. In Writing Tibetan History: The Discourses of Feudalism and Serfdom in Chinese and Western Historiography. Master's thesis, 1-29. East-West Centre, University of Hawaii.

Elliot, Mark C. 2014. 'Frontier Stories: Periphery as Centre in Qing History'. Frontier of History in China 9 (3): 336-36o.

Galli, Lucia. 2019. 'The Crafting Memory of the Self. Reflections on Tibetan DiaryKeeping'. Life Writing. DOI: http://dx.doi.org/10.1080/14484528.2019.1669427.

Gardner, Alexander P. 2006. The Twenty-five Great Sites of Khams: Religious Geography, Revelation, and Nonsectarianism in Nineteenth-Century Eastern Tibet. $\mathrm{PhD}$ dissertation, University of Michigan, Ann Arbor.

Giersch, C. Patterson. 2006. Asian Borderlands: The Transformation of Qing China's Yunnan Frontier. Cambridge, Mass: Harvard University Press.

Giersch, C. Patterson. 2010a. 'Cotton, Copper, and Caravans: Trade and the Transformation of Southwest China'. In Chinese Circulations: Capital, Commodities and Networks in Southeast Asia, edited by Wen-Ching Chang and Eric Tagliacozzo, 37-61. Durham, NC: Duke University Press.

Giersch, C. Patterson. 2010b. 'Across Zomia with Merchants, Monks, and Musk: Process Geographies, Trade Networks, and the Inner-East-Southeast Asian Borderlands'. Journal of Global History 5 (2): 215-239.

Giersch, C. Patterson. 2014. 'Commerce and Empire in the Borderlands: How Do Merchants and Trade Fit into Qing Frontier History?' Frontier of History in China 9 (3): $361-383$.

Giersch, C. Patterson. 2016. 'Afterword: Why Kham? Why Borderlands? Coordinating New Research Programs for Asia'. Cross-Currents: East Asian History and Culture Review 19: 202-213. URL: https://cross-currents.berkeley.edu/e-journal/issue-19/ giersch. Accessed 7 June 2019.

Goldstein, Melvyn C. 1968. An Anthropological Study of the Tibetan Political System. $\mathrm{PhD}$ dissertation, University of Washington. Photocopy of typescript. Ann Arbor, Michigan: University Microfilms International.

Goldstein, Melvyn C. 1971. 'Serfdom and Mobility: An Examination of the Institution of "Human Lease" in Traditional Tibetan Society'. The Journal of Asian Studies 30(3): 521-534.

Goldstein, Melvyn C. 1973. 'The Circulation of Estates in Tibet: Reincarnation, Land and Politics'. The Journal of Asian Studies 32 (3): 445-455. 
Goldstein, Melvyn C. 1986. 'Reexamining Choice, Dependency, and Command in the Tibetan Social System: “Tax Appendages” and Other Landless Serfs'. The Tibet Journal 11 (4): 79-112.

Goldstein, Melvyn C. 1989a. A History of Modern Tibet, 1913-1951: The Demise of the Lamaist State. Berkeley: University of California Press.

Goldstein, Melvyn C. 1989b. 'Interview Hoo59: with Sandutsang, Rinchen [tib. sa 'du tshang rin chen], (India, 26 August 1989): Part no. 1 of 2'. In Tibetan Oral History Archive Project (Asian Division), Library of Congress. URL: https://www. loc.gov/item/tohap.Hoo59/ Accessed 7 June 2019.

Goldstein, Melvyn C. 2007. A History of Modern Tibet. Volume 2: The Calm before the Storm (1951-1955). New Delhi: Munshiram Manoharlal Publishers.

Gros, Stéphane. 2016. 'Introduction to "Frontier Tibet: Trade and Boundaries of Authority in Kham"'. Cross-Currents: East Asian History and Culture Review 19: 1-26. URL: http://cross-currents.berkeley.edu/e-journal/issue-19/gros. Accessed 7 June 2019.

Gruschke, Andreas. 2004. The Cultural Monuments of Tibet's Outer Provinces: Kham. Volume 2: The Qinghai Part of Kham. Bangkok: White Lotus.

Harris, Tina. 2013. Geographical Diversions: Tibetan Trade, Global Transactions. Athens, Ga: University of Georgia Press.

Hartley, Lauran R. 1997. A Socio-Historical Study of the Kingdom of sDe-dge (Derge, Kham) in the Late Nineteenth Century: Ris-med Views of Alliance and Authority. MA thesis, Indiana University.

Hayes, Jack P. 2014. A Change in Worlds on the Sino-Tibetan Borderlands: Politics, Economies, and Environments in Northern Sichuan. Lanham, MD: Lexington Books.

Jackson, David P. 2003. A Saint in Seattle. The Life of the Tibetan Mystic Dezhung Rinpoche. Boston: Wisdom Publications.

'Jam dbyangs tshul khrims 1995. Khams stod lo rgyus thor bsdus. Volume 1. Lan khru'u: Kan su'u mi rigs dpe skrun khang.

Jamyang Norbu, 2014. 'The Political Vision of Andrutsang Gompo Tashi'. [Blog] Shadow Tibet. URL: http://www.jamyangnorbu.com/blog/2014/og/27/thepolitical-vision-of-andrugtsang-gompo-tashi/ Accessed 7 June 2019.

Kapstein, Matthew. 2006. The Tibetans. Malden, Mass.: Blackwell Pub.

Kha stag'Dzamyag. 1997. Phyi lo 1944 nas 1956 bod dang bal po rgya gar bcas la gnas bskor bskyod pa'i nyin deb / A Pilgrim's Diary: Tibet, Nepal and India 1944-1956, edited by Ācārya 'Jam dbyangs dbang rgyal. New Delhi: Indraprastha Press (CBT).

Kim, Kwangmin. 2008. Saintly Brokers: Uyghur Muslim, Trade, and the Making of Qing Central Asia, 1696-1814. Berkeley: University of California Press.

Lawson, Joe. 2011. Xikang: Han Chinese in Sichuan's Western Frontier, 1905-1949. Unpublished PhD dissertation, Victoria University of Wellington. 
Lhag pa don grub, 2009. 'De sngon bod ljongs nang khul dang bod hin bar gyi tshong las byed srol dang phyir gtong nang 'dren sogs kyi skor rags tsam'. In Bod kyi rig gnas lo rgyus dpyad gzhi'i rgyu cha bdams bsgrigs, 20 (1), 366-386. Khreng tu'u: Si khron mi rigs dpe skrun khang.

McGranahan, Carole. 2002. 'Sa spang mda' gnam spang mda': Murder, History, and Social Politics in 1920s Lhasa'. In Khams pa Local Histories: Visions of People, Place, and Authority: PIATS 20oo: Tibetan Studies: Proceedings of the Ninth Seminar of the International Association for Tibetan Studies, Leiden 20oo, edited by Lawrence Epstein, 104-125. Leiden: Brill.

McGranahan, Carole. 2010. Arrested Histories: Tibet, the CIA, and Memories of a Forgotten War. Durham, N.C.: Duke University Press.

McGranahan, Carole. 2015. 'On Social Death:The Spang mda'tsang Family and the $20^{\text {th }}$ Century Tibetan History'. In Festschrift for Elliot Sperling. edited by Gedun Rabsal, Roberto Vitali, and Nicole Willock, 199-205. Dharamsala: Amnye Machen Institute.

Miller, Beatrice D. 1987. 'A Response to Goldstein's “Reexamining Choice, Dependency, and Command in the Tibetan Social System"'. The Tibet Journal 12 (2): 67-68.

Miller, Beatrice D. 1988. 'Last Rejoinder to Goldstein on Tibetan Social System'. The Tibet Journal 13 (3): 64-66.

Mills, Martin A. 2003. Identity, Ritual and State in Tibetan Buddhism: The Foundations of Authority in Gelukpa Monasticism. London: Routledge Curzon.

Millward, James A. 1998. Beyond the Pass: Economy, Ethnicity, and Empire in Qing Central Asia, 1759-1864. Stanford, Calif.: Stanford University Press.

Peng, Wenbin. 2002. 'Frontier Process, Provincial Politics and Movements for Khampa Autonomy During the Republican Period'. In Khams pa Histories: Visions of People, Place and Authority. PIATS 20oo: Tibetan Studies: Proceedings of the Ninth Seminar of the International Association for Tibetan Studies, Leiden 20oo, edited by Lawrence Epstein, 57-84. Leiden: Brill.

Perdue, Peter C. 2005. China Marches West: The Qing Conquest of Central Eurasia. Cambridge, Mass.; London: Belknap Press of Harvard University Press.

Petech, Luciano. 2013. 'Aristocracy and Government in Tibet, 1728-1959'. In The Tibetan History Reader, edited by Gray Tuttle and Kurtis R. Schaeffer, 437-456. New York: Columbia University Press. [First edition 1973. Serie Orientale Roma, Volume 45. Rome: Istituto Italiano per il Medio ed Estremo Oriente]

Powers, John. 1995. Introduction to Tibetan Buddhism. Ithaca, N.Y.: Snow Lion.

Powers, John and Templeman, David. 2012. Historical Dictionary of Tibet. Lanham, Maryland: Scarecrow Press Publications.

Quintman, Andrew. 2015. The Yogin and the Madman: Reading the Biographical Corpus of Tibet's Great Saint Milarepa. New York: Columbia University Press.

Relyea, Scott. 2015a. 'Conceiving the "West”: Early Twentieth-Century Visions of Kham'. Modern China 4 (3): 181-200. 
Relyea, Scott. 2015b. 'Yokes of Gold and Threads of Silk: Sino-Tibetan Competition for Authority in Early Twentieth-Century Kham'. Modern Asian Studies 49 (4): 963-1009.

Relyea, Scott. 2016. 'Victorianizing Guangxu: Arresting Flows, Minting Coins, and Exerting Authority in Early Twentieth-Century Kham'. Cross-Currents: East Asian History and Culture Review 19: 122-146. URL: http://cross-currents. berkeley.edu/e-journal/issue-19/relyea. Accessed 7 June 2019.

Sadutsang, Rinchen. 2016. A Life Unforeseen: A Memoir of Service to Tibet. Boston: Wisdom Publications.

Samuel, Geoffrey. 1982. 'Tibet as a Stateless Society and Some Islamic Parallels'. Journal of Asian Studies 41 (2): 215-229.

Samuel, Geoffrey. 1993. Civilized Shamans: Buddhism in Tibetan Societies. Washington: Smithsonian Institution Press.

Smith, Gene E. 2001. Among Tibetan Texts: History and Literature of the Himalayan Plateau, edited by Kurtis R. Schaeffer. Boston: Wisdom Publications.

Spengen, W. van, 200o. Tibetan Border Worlds: A Geohistorical Analysis of Trade and Traders. London: Kegan Paul International.

Stein, Rolf A. 1972. Tibetan Civilization. Stanford, Calif.: Stanford University Press. Teichman, Eric. 1922. Travels of a Consular Officer in Eastern Tibet: Together with a History of the Relations between China, Tibet, and India. Cambridge: Cambridge University Press.

Travers, Alice. 2013. 'How Should we Define Social Status? The Study of "Intermediate Groups" in Central Tibet (1895-1959)'. In Tibetans who Escaped the Historian's Net: Studies in the Social History of Tibetan-speaking Societies, edited by Charles Ramble, Peter Schwieger and Alice Travers, 141-16o. Kathmandu: Vajra Books.

Tsomu, Yudru. 2013. 'Taming the Khampas: The Republican Construction of Eastern Tibet'. Modern China 39 (3): 319-344.

Tsomu, Yudru. 2015. The Rise of Gönpo Namgyel in Kham: The Blind Warrior of Nyarong. Lanham, MD: Lexington Books.

Tsomu, Yudru. 2016a. 'Guozhuang Trading Houses and Tibetan Middlemen in Dartsedo, The "Shanghai of Tibet"'. Cross-Currents: East Asian History and Culture Review 19: 71-121. URL: https://cross-currents.berkeley.edu/e-journal/ issue-19/tsomu. Accessed 7 June 2019.

Tsomu, Yudru. 2016b. 'Traders as Cultural Brokers on the Sino-Tibetan Borderland during the Republican Period'. Zangxue xuekan 藏学学刊 (Journal of Tibetan Studies) 14: 1-44.

Turek, Maria M. 2013. 'In This Body and Life': The Religious and Social Significance of Hermits and Hermitages in Eastern Tibet Today During Recent History. PhD dissertation, University of Berlin. 
Turek, Maria M. Forthcoming. 'Monastic Obligations, Hat Change and Lhasa Encroachment: Notes on the Economic System in the Historical Kingdom of Nang chen'. In When the Taxman Cometh: Tax, Corvée and Community Obligations in Tibetan Societies, edited by Charles Ramble, Peter Schwieger, and Alice Travers. Wang, Xiuyu. 2011. China's Last Frontier: Late Qing Expansion in Sichuan's Tibetan Borderlands. Lahnham, MD: Lexington Books.

Yul shul rdzong: dgon sde'i lo rgyus mdor bsdus [n.p./n.d.]. Yul shul rdzong srid gros, yul shul rdzong 'thab phyogs gcig sgril khang, yul shul rdzong mi rigs chos lugs don gcod khang [TBRC WooEGS1016676].

\section{About the Author}

LUCIA GALLI is a research fellow at the Centre de recherche sur les civilisations de l'Asie orientale (C.R.C.A.O., Paris) and a member of the École pratique des hautes études (EPHE - PSL), where she is currently working within the framework of the ANR/DFG funded research project Social Status in the Tibetan World (TibStat). She holds a DPhil in Oriental Studies from the University of Oxford with a thesis on the nyindep ('diary') of the Khampa trader Khatag Dzamyag. 
